\title{
Transparency as a Key Element in Accountability in Non-Profit Organizations: A Systematic Literature Review
}

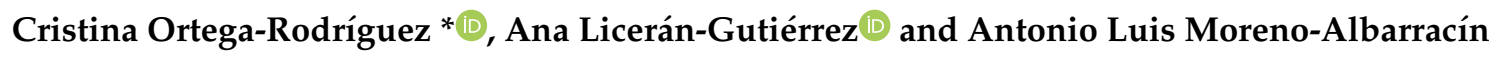 \\ Department of Financial Economics and Accounting, University of Jaén, Paraje Las Lagunillas, s/n, \\ E-23071 Jaén, Spain; aliceran@ujaen.es (A.L.-G.); almoreno@ujaen.es (A.L.M.-A.) \\ * Correspondence: corodrig@ujaen.es; Tel.: +34-953-21-19-07
}

Received: 6 June 2020; Accepted: 13 July 2020; Published: 20 July 2020

\begin{abstract}
The purpose of this article is to present a framework to understand transparency in the third sector and then to explore the main research streams regarding the disclosure of information and accountability by conducting a systematic literature review on the antecedents and dimensions of the transparency of information disclosed by non-profit organizations (NPOs). The essential questions of this work are addressed from an international perspective. In particular, we explore three research questions: (1) why should NPOs disclose transparent information to stakeholders? (2) Why do not all NPOs disclose transparent information? (3) What means do NPOs use to disclose transparent information? Our results highlight the lack of transparency legislation in the third sector, leading NPOs to adopt the voluntary disclosure of information policies to improve the perceived credibility of these entities by their stakeholders. In conclusion, our study highlights the importance of developing a systematic body of knowledge regarding the situation of transparent, voluntary information disclosure in the sector. Moreover, the Sustainable Development Goals promulgated by the United Nations place a high value on transparency for the accountability of institutions. To achieve sustainable development, both peace and the governance of institutions are needed. Reducing corruption and promoting transparency are among the goals which should be reached to achieve social sustainability.
\end{abstract}

Keywords: third sector; non-profit organizations (NPO); transparency; accountability; systematic literature review (SLR)

\section{Introduction}

Worldwide, the number, size and prominence of non-profit organizations (NPOs) is growing [1,2]; this growth is caused by the increase of social problems [3] of an economic, political, and religious nature etc. [4] NPOs are aimed at accomplishing functions intended to strengthen the social and ecological dimensions of sustainable development [5]. In this sense, the social mission of third-sector organizations is to meet collective demands that the public sector is not able to cover. To achieve this mission, they need the trust of their stakeholders, making it necessary that the actions carried out by NPOs are transparent [6]. Notwithstanding this fact, different cases of fraud have been observed in the sector [7]. This has raised new concerns about the quality of transparent information and the mechanisms for its disclosure and accountability to stakeholders. Although transparency is important for any organization, in the case of NPOs, it is especially relevant to demonstrate that the resources they receive are used to fulfill the purpose for which these organizations were conceived; credibility with society can mean the survival of the entity. A key aspect of credibility is the transparency of the information that NPOs disclose to their stakeholders [8]. 
Clarifying the concept of transparency is one of the most complex problems faced by the third sector $[9,10]$. In the extant literature on non-profit entities, there is no single definition that allows us to define transparency in our field of study. However, the value of transparency is implicit in the fact that the transparent disclosure of information by NPOs should provide their stakeholders with relevant and reliable information [11,12]. These entities are thus able to increase the confidence of stakeholders in their performance [12]. In this sector, a worrying absence of transparency has been detected [11], which is a delicate matter due to the potential loss of support from donors and volunteers, with a direct impact on the future of the organizations [13].

The activity that NPOs undertake is scrutinized by their stakeholders, who form their own opinions based on the level of fulfilment of their expectations and the attention received by the organization. For this reason, these entities should deepen the knowledge and understanding of their stakeholders [14]. The theoretical position of this work is based on the stakeholder theory, whose origin is based, among others, on fields such as organizational behavior, the policy of particular interests, and even the goals of the management team of a specific organization [15]. In 1984, the concept of the stakeholder was originally defined in the work on strategic management by Freeman [16]. This concept is linked to "groups of individuals that affect or are affected by the activity that is carried out by the firm to meet its organizational goals". The term is understood as "people, groups, firms, community and society that are interested in the growth of a firm" [17]. These groups have the legitimacy to demand the provision of certain quality services by NPOs, and in particular, to know the policies of the management of the resources in these entities. Transparency is an exercise of responsibility that an NPO must exercise by focusing its attention on how to respond to the expectations and demands of its stakeholders and on how to manage the organization to fulfill its mission and maintain its institutional legitimacy [18].

NPOs also face the challenge of contributing towards sustainable development and management [19]. Considering this, the present study is concerned with the Sustainable Development Goals, which call for urgent actions by all countries. The 2030 Agenda for Sustainable Development, adopted by all United Nations Member States in 2015, contains 17 Sustainable Development Goals (SDGs). We focus our attention on objective 16, which includes the following: "16.6: Develop effective, accountable and transparent institutions at all levels". The SDGs seek for solutions to eradicate poverty, improve the environment worldwide and achieve the enjoyment of peace and prosperity for all people. The SDGs aim for environmental, economic, and social sustainability. For that purpose, it is important to fight against poverty, hunger, and discrimination. However, it is additionally a priority to fight against practices of corruption and bribery, as well as to develop efficient and transparent accountability for different institutions; transparency contributes, undoubtedly, to improving the world. However, recent studies that have been conducted in the area of sustainable development have given very little consideration to NPOs [19].

The International Non-Governmental Organizations (INGO, hereafter) Accountability Charter, a cross-sectorial international regulatory initiative, is also of particular relevance in this study [20]. The INGO Accountability Charter [21] outlines 10 commitments to transparency and accountability which are essential to good governance by governments, businesses, or NPOs. We highlight Commitment 3, "Transparency", which includes the following: "The implementation of an open information policy which ensures timely, relevant and accurate information is disclosed in an accessible format (...), complying with the relevant governance, financial accounting and reporting requirements (...), basing disclosure of information...". The different commitments to accountability are at the core of what INGO regards as good practice in third-sector accountability [21].

Thus, NPOs worldwide face an increasing demand for accountability and improved transparency [22]. Henceforth, NPOs must be able to convince society that they have systems in place to assess the prudent management of received resources and funds [7]. We emphasize that the general trend observed internationally is the need to find tools that allow the improvement of information and management systems. For this purpose, NPOs should be able to develop systems that 
encompass the economic and the social value dimensions [23,24]. Consequently, traditional accounting and the models that provide economic-financial information are currently insufficient to reflect all aspects and characteristics of the social nature presented by NPOs [25-27].

NPOs should develop an accountability regime that reaffirms their important contribution to society, proposing an approach based on legitimacy [28]. Therefore, mechanisms that enable stakeholders to assess the appropriate destinations of resources according to their purpose and social mission are needed [13]. In this study, we analyzed the extant of research on the transparency of NPOs. The objective of our systematic literature review (SLR) is, first of all, to deepen the knowledge of NPO management and the understanding of the value that the concept of transparency has as an essential issue in accountability. Next, we analyze the state-of-the-art of the literature about transparency in NPOs, especially observing which of the published articles in our sample have adopted any kind of empirical procedure. Lastly, as a conclusion of this study, we also debate whether it is possible to establish a criterion for the measurement of transparency as a key aspect for the future of NPOs. This work aims to deepen the knowledge of transparency in the third sector. Despite the importance that the concept of transparency has for generating credibility with society, it is not a phenomenon that is widely studied. For this reason, we intend to expand the understanding of transparency measurement in NPOs. To do this, we carefully analyze the few articles in the prior literature that have specifically addressed this issue as their focus of research. Our study, thus, aims to contribute to addressing an important research topic that requires wider development in the literature.

There are several reasons that justify the need for an SLR: (i) the importance of transparency in any organization, but specifically its special characteristics for NPOs; (ii) the demands of information from stakeholders; (iii) the absence of a single definition of transparency; and (iv) the scarcity of studies in the field and the lack of uniform measurement procedures to determine the level of transparency of an NPO. All of these factors lead us to attempt to deepen the knowledge of this field, which, thus far, has been little studied.

The structure of the paper proceeds as follows. Section 2 discusses the uniqueness of these organizations, showing the characteristics of the non-profit environment. The description of the SLR is given in Section 3. The results of the SLR are described in Section 4. Section 5 explains the building blocks of the theoretical foundation on the disclosure of transparent information in NPOs, divided into three research questions. Finally, conclusions are presented in Section 6.

\section{Characteristics that Define the NPOs}

The purpose of this section is to add knowledge regarding the characteristics that define NPOs. Firstly, there are many parties who are interested in knowing if an organization has developed adequate management practices, and for this reason, they must disclose useful information to their stakeholders that justifies the use of their money. For this purpose, one of the characteristics of the information disclosed by NPOs is its appropriate extent of transparency. Transparency must ensure that the received funds do not deviate from their social mission, incurring an irresponsible expense [13].

Secondly, NPOs perform some of the most important functions which support and strengthen society and, thus, play a crucial role $[29,30]$. NPOs lack a purely lucrative purpose, with their main objective being the achievement of their social mission [31,32]. Thus, their focus is not profit; the non-profit nature of their activity invalidates the measurement of the earnings surplus as an indicator of success in an NPO. Therefore, success cannot be measured from a financial perspective because this will not be the organization's main objective. Accordingly, using only financial measures may not be representative of the performance of NPOs [33]. The different focuses of these organizations in comparison with other sectors mean that NPOs measure their economic performance in different ways [34].

Thirdly, NPOs are not allowed to distribute any kind of earnings surplus. Notwithstanding this limitation, NPOs can economically compensate their employees or volunteers for their work, but such organizations are subject to a total or significant ban on any distribution of their earnings [32,35]. 
Fourthly, entities from the third sector raise public funds and are subject to a favorable tax regime to carry out their activity [36]. Traditionally, NPOs are subject to less strict government regulation than public or private-sector entities [11]. It is essential to provide greater visibility for their actions and avoid suspicions of irregularities regarding tax advantages and fundraising from public administrations [6].

Finally, the fact of acting in favor of social purposes means that these entities count on a great number of volunteers to carry out their activity. In this sense, the extant literature considered a possible lack of professionals in the management of NPOs [37]. However, an increasing professionalization of staff has been observed [38,39], which means that adequate management requires the hiring of professionals by NPOs.

In addition, the following concepts should be analyzed in advance: The term "accountability" includes the disclosing of information, in response to stakeholder concerns, enabling their participation in the organization and evaluation of its performance [40,41]. This can be catalogued as a multidimensional concept [42]. The term "transparency" is linked to a variety of issues, but mainly to information disclosure $[30,43,44]$. Thus, non-profit transparency and accountability are two connected concepts, with transparency referring to how much information is disclosed by NPOs, which contributes to their accountability [45].

For several reasons, transparency is especially relevant in the third sector. NPOs that disclose transparent information demonstrate that they act following a set of good practices, have good governance, explain the use of their received funds, and make information public [46]. Transparency provides greater visibility for the organization's actions and avoids the appearance of suspicions and alleged irregularities [6]. Additionally, it is convenient to keep in mind that the academic interest in the transparency of NPOs comes from the widespread development of the third sector over recent years [1,47]. Taking these definitions into account and assuming the importance of the role of transparency in the third sector, whenever we refer to "transparency in NPOs" in this document, we mean the moral practice of accountability by which these organizations have to disclose information on the activities they carry out and the resources they use to achieve their social purpose; i.e., their mission $[42,48]$.

In conclusion, the importance of increasing the credibility of NPOs to raise the necessary funds reinforces the need to design and implement management and internal control systems that are capable of providing social and economic-financial information on the performance of the NPOs. Moreover, NPOs will be perceived as more credible if the information disclosed to their stakeholders is more transparent.

To conclude this section, as previously stated in the introduction, the theoretical position of this work is based on the stakeholder theory. Stakeholder theory has its origins in 1984, when the concept "stakeholder" was studied by Freeman (1984) [16] and used to refer to "any group or individual who can affect or is affected by an organization's achievements" (Freeman, 1984, p. 46) [16]. This theory has attracted increased interest from non-profit researchers [49], because this theory leads to value creation given that it meets the expectations of various stakeholders in the context of information transparency [4]. NPOs have to identify the significant information for each stakeholder and from there develop and use certain tools that allow the firm to actually meet the reporting demands of stakeholders [4]. The ability of stakeholders to access organization-specific information concerning the operations of an NPO is important for donation decisions [50]. Analyzing disclosure patterns among NPOs matters because many current and potential stakeholders are contributing by expending their time and money and, therefore, want to know if it is used efficiently [50].

Next, we present a bibliometric review on transparency in the third sector, especially focusing on its measurement in prior literature. The section below presents the methodology followed in the present study. 


\section{Description of the Bibliometric Review}

In this section, we describe the process of our bibliometric review of transparency in the third sector. This review aimed to extract the main theoretical rationales, highlights, and challenges from our field of study by analyzing a series of articles in a systematic and methodological way. For this purpose, multiple research methodologies were employed. The methods used to analyze the theoretical concepts of selected articles could be either automated methods (such as text mining) or manual methods (such as an SLR). Whichever the adopted methodology, the study led to an exhaustive search to collect all the relevant research articles in our field.

We can find advantages for the use of both methods. On the one hand, text mining is a research technique which examines a large collection of texts in order to answer specific research questions. The texts that are used as resources can be scientific articles, among others [51]. Text mining identifies facts, relationships, and assertions that would otherwise remain hidden. On the other hand, SLR employs a strict search protocol and evaluation of literature and is a standardized method; that is, it is replicable, transparent, objective, unbiased, and rigorous [52].

Comparing the disadvantages of applying one versus the other method, text mining is based on data mining, machine learning, and natural language processing which is then applied to the text, relying on computer programs and algorithms [51]. Therefore, text mining does not pay attention to the active role of the researcher because text should be coded and analyzed by the computer program [51]. This fact increases the complexity of the use of this approach. Meanwhile, an SLR consists of a "manually" detailed reading, interpretation, and analysis of scientific articles, which may increase the time consumption and difficulties of undertaking such a task.

In detail, text mining extracts relevant words and the relationships between words to classify them and draw relevant conclusions [53]. For some examples in literature, Basuony, et al. (2020) [54] used text mining in order to extract topics regarding corporative internet disclosure, while Yang, et al. (2018) [55] used text mining to extract topics from corporative risk and audit fees. In a similar way to the aforementioned studies, we could use this method to extract topics from the disclosure of transparent information in the third sector. This technique, however, may not correctly fit with the analysis of transparency measurement in the third sector. The main problem is the lack of conceptualization regarding the organizations that make up the third sector, which is still subject to deep debate [56], as well as the absence of a clear and rigorous definition of transparency. In this regard, many authors have attempted to overcome the challenges that such a formulation poses when using text mining [35,57-60]. Because this technique extracts the main words and concepts from a series of analyzed articles, the frequency with which the exact concepts appear in the texts affects whether they are considered a key concept in text mining. As an example, if the most-used word in the text is "NPO" and its relation to "TRANSPARENCY" for the majority of the articles; other articles that use different terms that also define the same theoretical reality (such as "THIRD SECTOR", "NGO", or "TSO") would be ignored. All these terms are among the prism of descriptions of entities whose main goal is not to obtain profits but to pursue a social mission. This fact adds additional complexity to our work in the use of text mining, because it may lead to an exclusion of articles that are considered relevant in our field of study.

In contrast, the traditional SLR based on the manual selection of articles allows-through Boole algebra commands- the building of data sets to study relationships between theoretical concepts. This fact of manually defining the search commands makes it more suitable for a literature review in our field of research. Considering all the above, we finally adopted a manual technique for our SLR. This allowed us to use different terms to define organizations that make up the third sector and relate them to the concept of transparency. In detail, we used the following commands: "NONPROFIT", "NON PROFIT", "NON-PROFIT", "NPO", "THIRD SECTOR", "THIRD-SECTOR", "NGO", “NON-GOVERNMENTAL ORGANIZATION", "NON GOVERNMENTAL ORGANIZATION", "TSO", and "NONGOVERNMENTAL ORGANIZATION". The SLR was structured in different phases, which are described below. 


\subsection{Planning the Review: Formulation of the Research Questions}

The planning phase consisted of formulating the research questions (RQs) that emerged due to the gaps in the prior literature that were detected in our field of research. Thus, it was relevant to enumerate these questions first for the better understanding of the different search criteria phases.

After deepening our study in this sector, we detected the difficulties for NPOs regarding transparent information disclosure. Due to the lack of legal rules that make this task compulsory for NPOs, some of these entities have opted to voluntarily disclose information. Thus, we faced a complex problem that led us to reconsider the main purpose of this review; we therefore focused on answering the RQs presented and analyzed below.

- $\quad$ RQ1: Why should NPOs disclose transparent information to stakeholders?

- RQ2: Why do not all NPOs disclose transparent information?

- RQ3: What means do NPOs use to disclose transparent information?

Later, in Section 5, "Theoretical foundations on transparency in NPOs", we will define and explore these RQs.

\subsection{Search Criteria}

Having listed the three RQs as the basis for this review, we present each of the search criteria phases (See Figure 1 based on the PRISMA) flow diagram [61]). An SLR enables us to identify, analyze, and synthesize the existing body of literature in a clear way. The analysis was conducted in five phases (apart from the planning phase). Next, we describe the eligibility criteria included in each phase.

To begin with, we looked for extant literature on "transparency as a key element in accountability in non-profit organizations" with an electronic database search in the Web of Science, as this database is the one that includes the most significant publications on the issue of research in our study. The journals included in the Web of Science follow high-impact and quality standards. In fact, other studies in the prior literature specifically undertaking a literature review have also used this database [62-64].

The analyzed period of study includes those works published between 2005 and 2019 (both inclusive). The origin of the financial crisis of 2008 was linked to the effect of the real estate bubble in the United States in 2006. This caused the so-called subprime mortgage crisis in October 2007. The particular circumstances surrounding the economic crisis period were also reflected in relevant changes in the third sector. This reality made the activity of the third sector difficult because of problems of fundraising for NPOs due to the policies of reducing public spending together with the crash of the financial sector. Consequently, these entities had to find other means to obtain the financing to carry out their activities and satisfy the needs of their users. This situation created a new scenario in which NPOs had to carry out their missions. Therefore, we focus the starting date of our work on the years in which the financial crisis emerged and extend the study up to the present moment. We chose 2005 as the starting year because the aim of our work is to analyze works published over a 15-year time period. To limit the scope of our study, the eligibility criteria for papers to be included in the sample were as follows.

First, we used different connected terms related to the organizations that make up the third sector. In detail, we ran an advanced search with the following command: TS = (("NONPROFIT" OR “NON PROFIT" OR “NON-PROFIT" OR “NPO*” OR “THIRD SECTOR" OR “THIRD-SECTOR" OR “NGO" OR “NON-GOVERNMENTAL ORGANIZATION" OR “NON GOVERNMENTAL ORGANIZATION" OR “TSO" OR "NONGOVERNMENTAL ORGANIZATION") AND "TRANSPARENCY"). Thus, we searched for papers whose topic (TS) was related to the main focus of our study (transparency) regarding NPOs, including several later expressions in prior literature that have been associated with these entities (all of these expressions were considered as alternative, rather than exclusive; for that reason, we group them with the command "OR") (due to the lack of agreement on the conceptual development of the framework in our study, as well as the great variety 
of denominations regarding the organizations that make up the third sector, we have opted to limit the search commands in some way. This fact may have meant that relevant studies were not finally included in our sample (see, for example, [65-67])). As a result of this search, 449 articles were found.

Second, we only accepted 215 articles that were published in 19 English-language journals (JCR), 2019 version.

Third, we limited our study to the closest categories to our research field: social issues, management, business, business finance, ethics, and economics. In this phase, 79 articles were accepted.

Fourth, after an initial reading of the title, abstract, and keywords, 58 articles were selected. These studies met the criteria in this phase because they focused on transparency in the third sector. For this reason, they were considered relevant in this phase.

After reading each article in depth, we observed in the last phase that four articles were not directly related to our object of study. They were records that did not entirely match our focus. For this reason, they were not considered in the final analysis, as it was clear that they did not study transparency in the third sector. Finally, as the aim of this article was to develop knowledge of these issues through a final reading process of the 54 papers that constituted the fundamental basis for the discussion of this work, a synthesis was made to prepare a theoretical framework document.
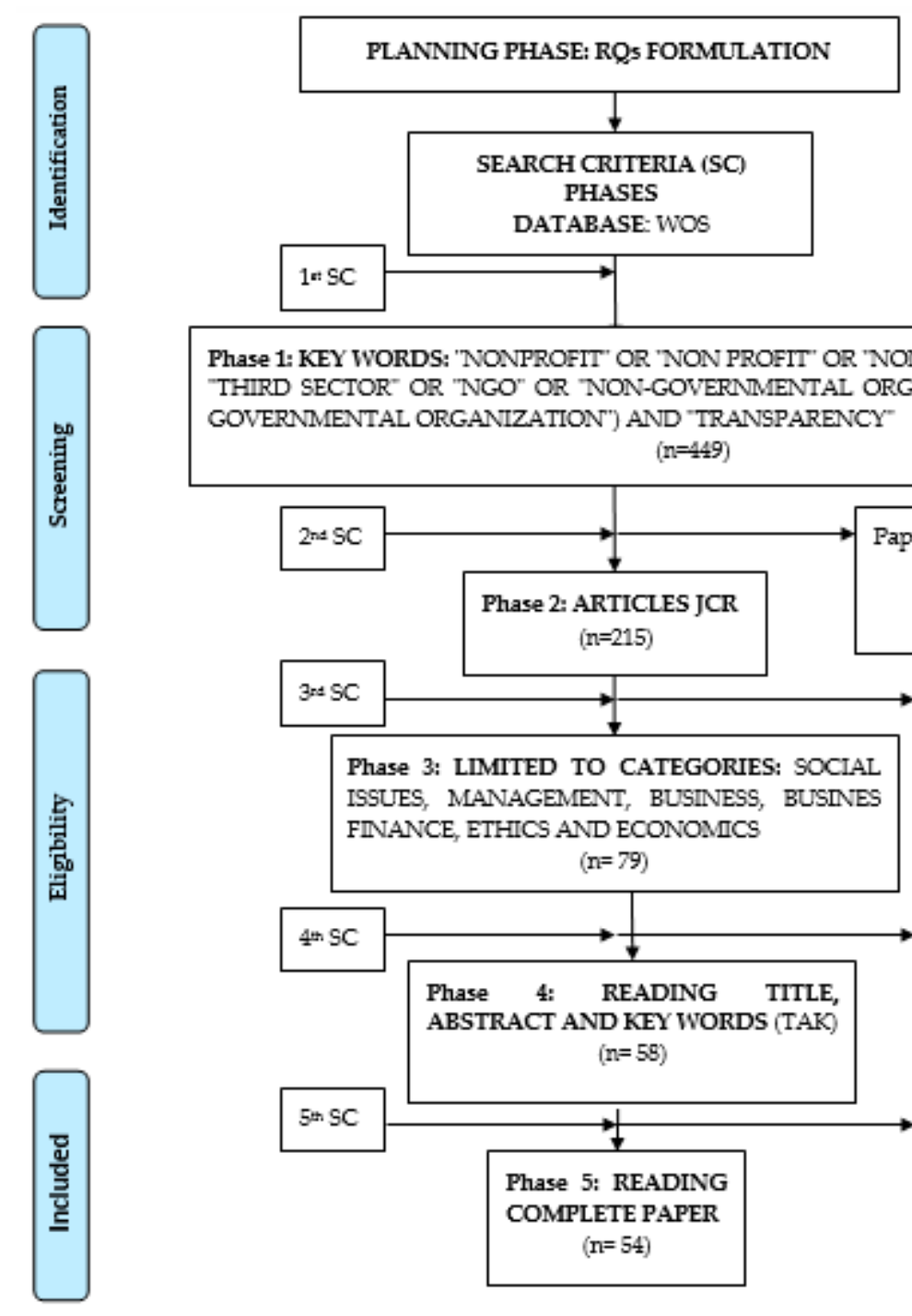

Phase 1: KEY WORDS: 'NONPROFIT' OR 'NON PROFIT' OR 'NON-PROFIT' OR "NPO' OR "THIRD SECTOR" OR "NGO" OR NON-GOVERMMENTAL ORGANIZATION" OR 'NON GOVERNMENTAL ORGANIZATION") AND "TRANSPARENCY" $(n=449)$

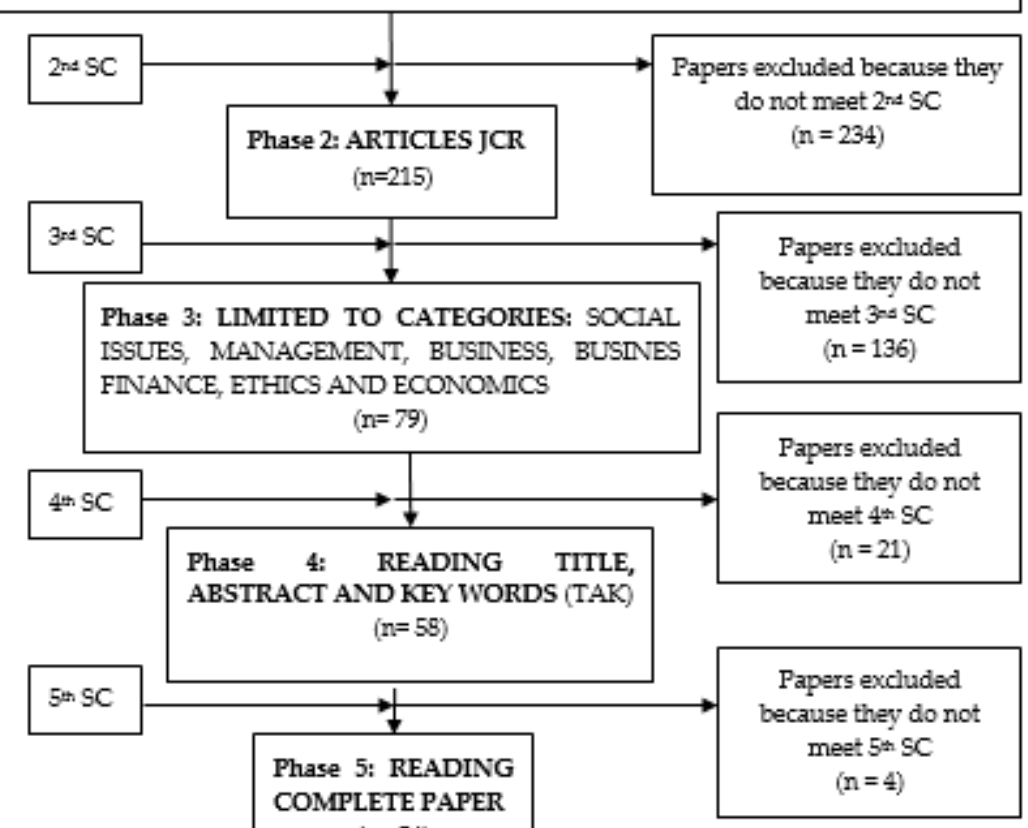

Figure 1. Phases of the systematic literature review (SLR) based on the PRISMA 2009 Flow Diagram. RQ: research question. 


\section{Results of the Systematic Literature Review: Sample Description}

In this section, the results that emerged from the SLR are described. For a better understanding of the data obtained, the presentation of these results is divided according to different typologies: "journals", "sample selection period", and "research methods".

\section{- Journals}

The 54 studies which constituted the final sample were published in 19 journals. Figure 2 presents the number of papers in each journal during the period 2005-2019. As can be observed, almost $55.56 \%$ of the papers selected were published in three specific non-profit journals: Nonprofit and Voluntary Sector Quarterly, Nonprofit Management \& Leadership, and VOLUNTAS: International Journal of Voluntary and Nonprofit Organizations. The rest of the papers (44.44\%) were published in other Social Sciences journals that were not specifically focused only on third sector research topics.

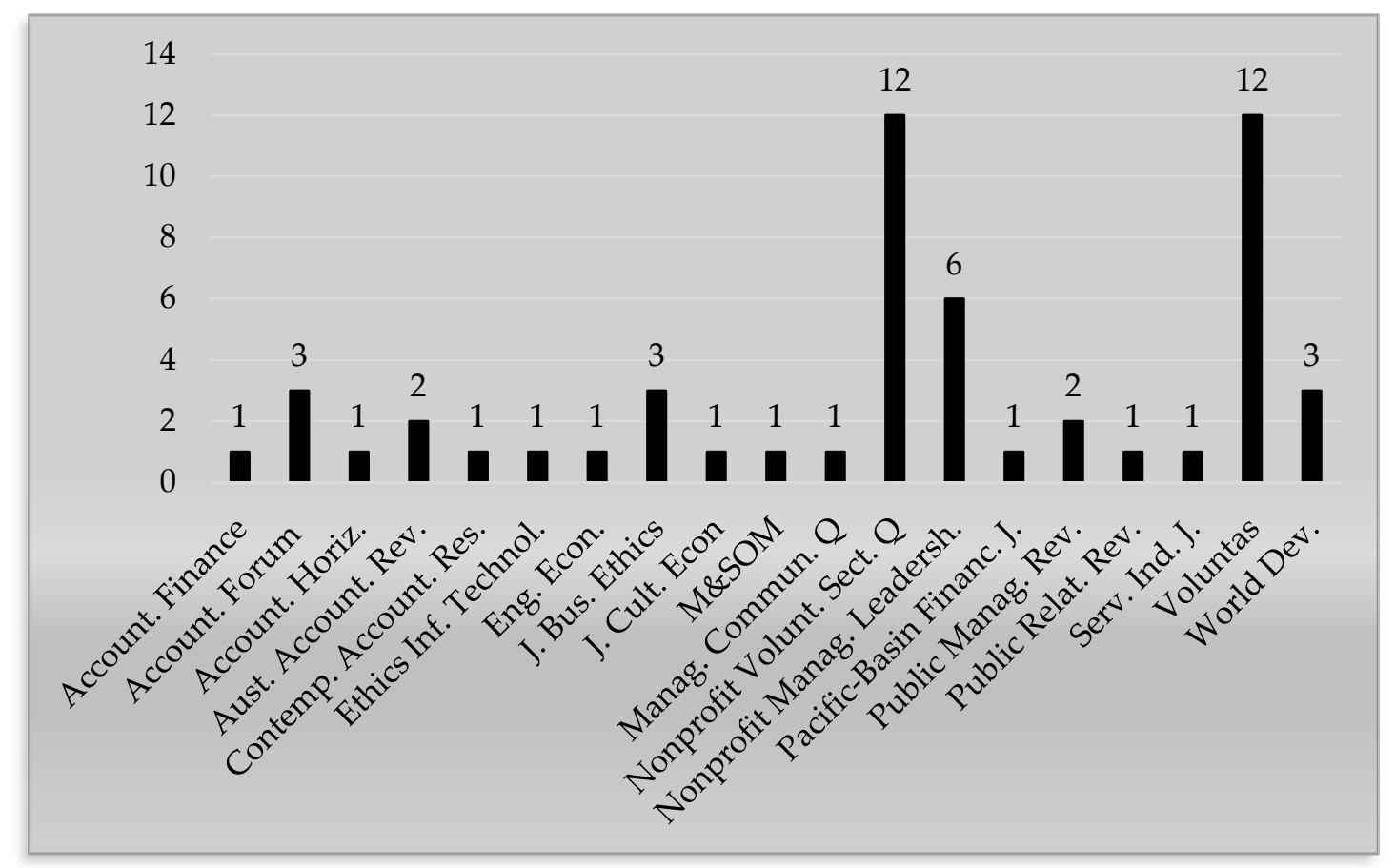

Figure 2. Number of publications per journal.

- $\quad$ Sample selection period

Once the 19 journals that made up our final sample were detailed, we continued to study complementary aspects. Table 1 indicates the following: column (1) shows the number of articles published by the 19 journals that make up our sample in the last 15 years analyzed. Column (2) presents the number of articles that have been published in the 19 magazines on the third sector in the last 15 years. Lastly, column (3) reports the number of articles published during the sample-selection period on transparency in the third sector. 
Table 1. Total articles published in the 19 journals from 2005 to 2019.

\begin{tabular}{cccc}
\hline 15 years & $\begin{array}{c}\text { (1) Articles Published } \\
\text { in 19 Journals }\end{array}$ & $\begin{array}{c}\text { (2) Articles on the Third } \\
\text { Sector in 19 Journals }\end{array}$ & $\begin{array}{c}\text { (3) Articles on Transparency in the } \\
\text { Third Sector in 19 Journals }\end{array}$ \\
\hline 2005 & 884 & 20 & 0 \\
2006 & 893 & 34 & 3 \\
2007 & 936 & 28 & 2 \\
2008 & 1.234 & 37 & 0 \\
2009 & 1.400 & 97 & 3 \\
2010 & 1.321 & 104 & 5 \\
2011 & 1.334 & 94 & 7 \\
2012 & 1.345 & 120 & 3 \\
2013 & 1.341 & 119 & 3 \\
2014 & 1.352 & 133 & 5 \\
2015 & 1.538 & 145 & 3 \\
2016 & 1.439 & 156 & 4 \\
2017 & 1.569 & 156 & 6 \\
2018 & 1.716 & 149 & 3 \\
2019 & 1.735 & 163 & 7 \\
Total & 20.037 & 1.555 & 54 \\
\hline
\end{tabular}

In accordance with the information from Table $1,7.76 \%$ of the articles published in the selected journals had the third sector as their main analysis question. Regarding this percentage, only $3.47 \%$ were focused on the study of transparency in the non-profit field. Thus, of the total number of articles published $(20,037), 54$ of them had transparency in the third sector as their main subject of study. This last category represents $0.27 \%$ of the total articles published. Table 1 also shows an increase in the number of articles during this period published by our journal sample (column). Besides this, there is also growing interest in the study of the third sector as shown by the data referring to the period (column 2).

After screening the records on general eligibility criteria, 54 articles regarding transparency as a key element in accountability in the NPOs remained.

At a glance, column (3) shows an increasing trend in the number of articles on transparency in the NPOs published by the journals in our sample during the analyzed period. Despite this growth, the data show that studies addressing this issue in the third sector are still scarce, thereby highlighting the need for an increase of research into non-profit information disclosure [68]. In more detail, we highlight two significant periods in the study of transparency in NPOs: The first period is the interval from 2010 to 2011, in which a total of 12 articles were published in the selected journals-this represents $22.22 \%$ of the total articles from our final sample-and the second period ran from 2017 to 2019, in which 16 articles were published, which represents $29.63 \%$ of the total (54 articles). Both periods bring together more than half of the publications on transparency in NPOs in the last 15 years.

\section{- $\quad$ Research method}

The distribution of papers according to research method is shown in Figure 3. This shows that the field of transparency in the third sector has been widely analyzed from the empirical point of view $(77.78 \%)$. Remarkably, there have been few empirical studies which have measured the levels of transparency in this sector. To be precise, $14.28 \%$ (6 out of 42) papers dealt with this research issue, representing $11.11 \%$ ( 6 out of 54 ) of the final sample. On the other hand, the remaining $22.22 \%$ studies were theoretical articles which do not provide an empirical method. 


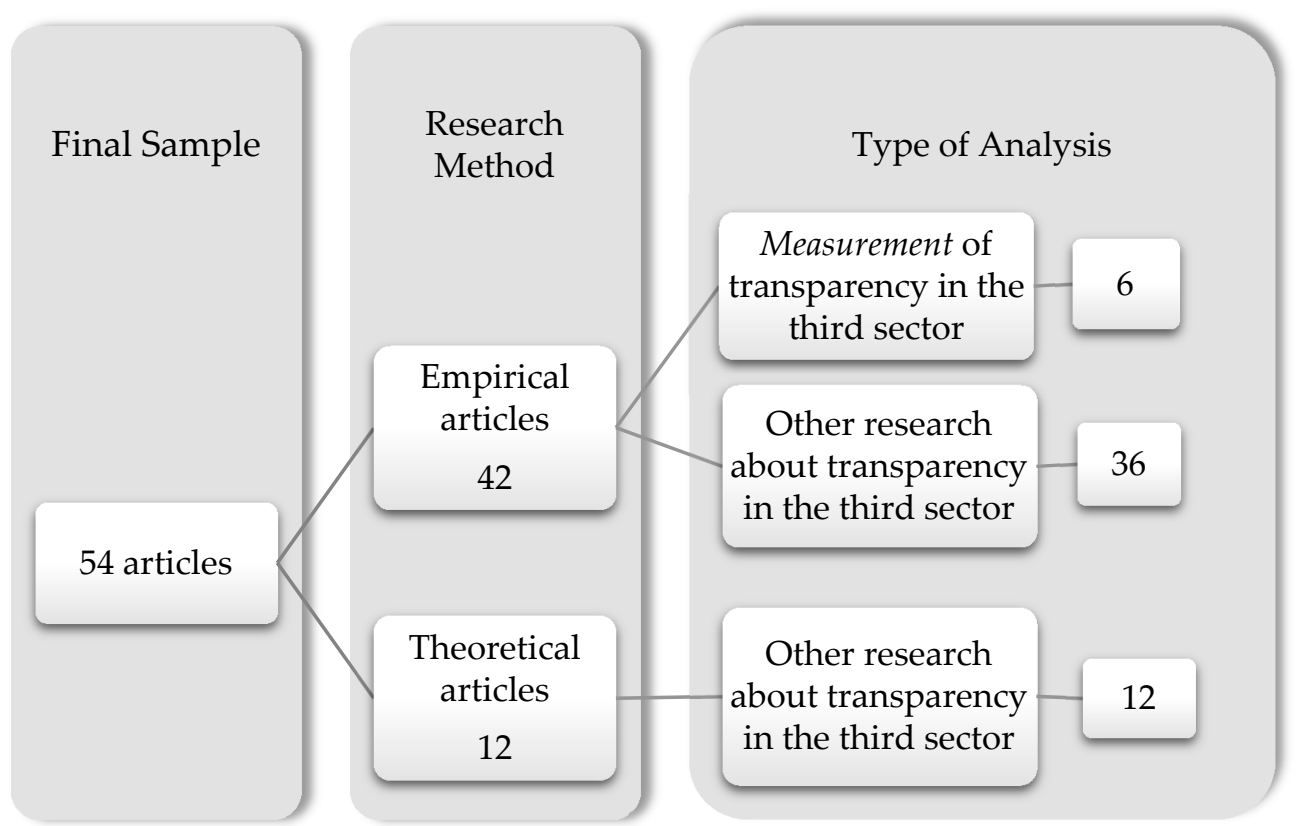

Figure 3. Number of publications by research method.

Focusing on the 42 papers that empirically analyzed transparency in the third sector, only six empirical studies measured this concept. In other words, despite the abundance of empirical studies, very few studies have attempted to measure the levels of transparency in the sector. Table 2 summarizes those articles, detailing their sample selection, the analysis statistical method, and a summary of the major findings.

Table 2. Measurement of transparency in the third sector. NPO: non-profit organization.

\begin{tabular}{|c|c|c|c|}
\hline Author (Year) & Focus of Study and Sample & Method & Summary of Sajor Findings \\
\hline $\begin{array}{l}\text { Burger, R., \& Owens, T. } \\
\text { (2010) }\end{array}$ & $\begin{array}{l}\text { Self-reported data to analyze } \\
\text { transparency in the NGO } \\
\text { (Non-governmental organizations) } \\
\text { Uganda using a questionnaire to collect } \\
\text { information on the organization's } \\
\text { structure, finances, and activities; and an } \\
\text { interview with a community focus } \\
\text { group to explore how the organizations } \\
\text { are perceived by community members. }\end{array}$ & $\begin{array}{c}\text { Pearson's chi-squared } \\
\text { test. }\end{array}$ & $\begin{array}{l}\text { - Reported levels of transparency in the } \\
\text { sector and accountability were } \\
\text { reasonably high. } \\
\text { - } 85 \% \text { of NGOs that produced annual } \\
\text { reports asserted that it was available to } \\
\text { the public upon request. } \\
\text { - NGOs claiming to be transparent may } \\
\text { frequently provide inaccurate } \\
\text { information, to show a more } \\
\text { favorable view. }\end{array}$ \\
\hline $\begin{array}{c}\text { Cabedo, J. D. } \\
\text { Fuertes-Fuertes, I. } \\
\text { Maset-LLaudes, A. \& } \\
\text { Tirado-Beltrán, J. M. } \\
\text { (2018) }\end{array}$ & $\begin{array}{l}\text { Analyze the level of transparency of the } \\
\text { portfolio of projects, detect the specific } \\
\text { aspects that could be improved in each } \\
\text { organization, and carry out comparisons } \\
\text { among NPOs. } \\
\text { The sample of this research was selected } \\
\text { from organizations that belong to } \\
\text { CONGDE (Spanish Development } \\
\text { NGO Coordinator). }\end{array}$ & $\begin{array}{l}\text { Index to measure the } \\
\text { information (technical, } \\
\text { financial, and scope) } \\
\text { transparency of the } \\
\text { projects implemented. }\end{array}$ & $\begin{array}{l}\text { - This index also uses the individualized } \\
\text { analysis of the items included in it to } \\
\text { determine the particular aspects in } \\
\text { which transparency could be improved. } \\
\text { - Social impact of the projects is } \\
\text { information that is not disclosed by any } \\
\text { of the organizations analyzed. }\end{array}$ \\
\hline Gandía, J. L. (2011) & $\begin{array}{l}\text { Empirical study through a proposed } \\
\text { model of information disclosure for the } \\
\text { evolution of the websites to improve } \\
\text { accountability and transparency. The } \\
\text { sample of this study was selected from } \\
\text { organizations rated by CONGDE. }\end{array}$ & $\begin{array}{l}\text { Transparency index } \\
\text { (Transparency index } \\
\text { based on the work } \\
\text { carried out by other } \\
\text { authors [69-71] and } \\
\text { transparency and } \\
\text { accountability } \\
\text { recommendations [72].) } \\
\text { and analysis of reliability } \\
\text { based on } \\
\text { Cronbach's alpha. }\end{array}$ & $\begin{array}{l}\text { - Donations are positively related to the } \\
\text { amount of information disclosed on } \\
\text { the web. } \\
\text { - Voluntary disclosure of information } \\
\text { provides signals and information that } \\
\text { are relevant to current and } \\
\text { potential donors. }\end{array}$ \\
\hline
\end{tabular}


Table 2. Cont.

\begin{tabular}{|c|c|c|c|}
\hline Author (Year) & Focus of Study and Sample & Method & Summary of Sajor Findings \\
\hline $\begin{array}{l}\text { Gálvez Rodríguez, M. M.; } \\
\text { Caba Pérez, M. C. \& } \\
\text { Godoy, M. L. (2012) }\end{array}$ & $\begin{array}{l}\text { A sample of } 130 \text { NGOs that were } \\
\text { voluntarily analyzed by Loyalty } \\
\text { Foundation was utilized to obtain the } \\
\text { necessary information through its webs. }\end{array}$ & $\begin{array}{l}\text { Disclosure Index (IDI) } \\
\text { and multivariable linear } \\
\text { regression analysis. }\end{array}$ & $\begin{array}{l}\text { - The use of the Internet in Spanish } \\
\text { NGOs to disclose information is scarce. } \\
\text { - More accountability mechanisms that } \\
\text { promote the Internet as a tool for the } \\
\text { communication and interaction } \\
\text { are needed. }\end{array}$ \\
\hline $\begin{array}{l}\text { Valencia, L. A. R., } \\
\text { Queiruga, D., \& } \\
\text { González-Benito, J. } \\
\text { (2015) }\end{array}$ & $\begin{array}{l}\text { Empirical analysis of } 62 \text { organizations } \\
\text { from the CONGDE studying the } \\
\text { indicators from Loyalty Foundation. }\end{array}$ & $\begin{array}{l}\text { Multiple regression } \\
\text { models. }\end{array}$ & $\begin{array}{l}\text { - Reporting on aspects related to four } \\
\text { transparency variables (administration, } \\
\text { project details, source of funds and use } \\
\text { of funds) is linked to greater efficiency in } \\
\text { the allocation of funds. }\end{array}$ \\
\hline $\begin{array}{l}\text { Yasmin, S., Haniffa, R., \& } \\
\text { Hudaib, M. (2014) }\end{array}$ & $\begin{array}{l}\text { Design of a research instrument to } \\
\text { capture transparency through the } \\
\text { qualitative characteristics of the Trustees } \\
\text { Annual Report and accountability with } \\
\text { the Statement of Recommended Practice } \\
\text { and Scale Stewart Accounts (1984) } \\
\text { (Stewart, J. D. (1984). The role of } \\
\text { information in public accountability. In } \\
\text { Hopwood, A. \& Tomkins, C. (Eds.), } \\
\text { Issues in public sector accounting. } \\
\text { Oxford: Philip Allen.). The population } \\
\text { consisted of Muslim Charity } \\
\text { Organization (MCOs) registered with } \\
\text { the Charity Commission for England } \\
\text { and Wales. }\end{array}$ & $\begin{array}{l}\text { Parametric independent } \\
\text { sample } t \text { test and } \\
\text { non-parametric } \\
\text { Mann-Whitney U test. }\end{array}$ & $\begin{array}{l}\text { - There is a lack of commitment in } \\
\text { substantive accountability for several } \\
\text { reasons: High donor confidence; weak } \\
\text { demand for information from the } \\
\text { stakeholders; internal organizational } \\
\text { problems related to organizational } \\
\text { structure and culture; and lack of } \\
\text { internal professional. }\end{array}$ \\
\hline
\end{tabular}

As a general conclusion of this section, we point out the scarce attention paid to transparency measurement. Nevertheless, it is worthwhile to highlight some relevant findings regarding these six articles. Firstly, a variety of methods are observed which can be grouped into three types of analyses:

- Regression models. This kind of method looks for the relationships of transparency with other variables. For instance, some authors aim to identify the influence of several factors because of the varied views on the weighting of the information disclosure of web pages [73]. Other authors study the relationship between transparency and efficiency in the allocation of funds in the NPOs [74].

- Statistical tests: This method is a more descriptive analysis, although it is used to give meaning to the aims of a study as a result. On the one hand, authors use non-parametric tests such as the Pearson's chi-squared test to explore why NPOs would not comply with transparency and accountability standards and provide inaccurate information about their compliance [11]. On the other hand, Yasmin, Haniffa, and Hudaib [75] combine the non-parametric Mann-Whitney U test and parametric independent sample t-test in order to examine communicated accountability practices.

- Index. Lastly, a group of studies used indices to summarize, with a single, reliable, and consistent measure, several aspects that are indicative of the extent of transparency in NPOs. To begin with, Gandía [12] analyzed the information transparency on the websites of Spanish NGDOD through a transparency index which consists of four sections, checking its internal consistency through an analysis of reliability based on Cronbach's alpha. Next, Gálvez Rodríguez et al. [73] used a Disclosure Index (IDI) to analyze the information provided in the organization web pages, regarding some principles of the Loyalty Foundation code. Finally, Cabedo et al. [30] proposed an index for measuring the level of transparency in relation to the projects of an organization, as well as determining the specific aspects in which transparency could be improved.

Therefore, it follows that there is no single way to measure transparency. Different techniques-in particular, regression models, indexes, and statistical tests-have been used to answer specific questions.

Consequently, the types of specific questions answered by the articles summarized in Table 2 do not result in a quantifiable level of transparency that can serve as a guide for stakeholders to determine how money and resources are being managed in the NPO to which they have allocated funds. This generates a gap in the literature to be covered: The quantification of the level of transparency 
objectively in an NPO is an open question. Thus, it is necessary to find the most suitable technique to measure transparency levels to cover this purpose.

Finally, we highlight that four of the six articles that empirically measure some aspect of the transparency in these organizations have their focus of study and sample in the "Spanish case". To do this, they rely on the two main entities that have developed a system for measuring transparency through indicators: The Spanish Development NGO Coordinator (CONGDE) and the Loyalty Foundation.

The Spanish Development NGO Coordinator (CONGDE), founded in 1986, is the main platform for this kind of organization in Spain. Since 1998, the CONGDE has used a code of conduct binding on all partner organizations. Moreover, the "Transparency and Good Governance Tool" is a pioneering initiative whose application has been compulsory for all entities and platforms since 2012. In a similar manner, the Loyalty Foundation also has a code of conduct; besides this, the organization measures the transparency of its participants who work in global areas and are intentionally involved with an accountability mechanism. This work has been carried out since its creation in 2001, based on its values of independence, transparency, solidarity, and rigor.

In conclusion, we summarize the analysis of transparency measurement studies in Table 3, classifying each article according to the methodology and sample context.

Table 3. Methodology and sample context of the studies measuring transparency.

\begin{tabular}{|c|c|c|c|c|c|c|c|}
\hline \multirow{3}{*}{ Author (Year) } & \multirow{2}{*}{\multicolumn{4}{|c|}{ Method }} & \multicolumn{3}{|c|}{ Sample } \\
\hline & & & & & \multicolumn{2}{|c|}{ Spanish Context } & \multirow{2}{*}{ Other } \\
\hline & $\begin{array}{l}\text { Regression } \\
\text { Models }\end{array}$ & $\begin{array}{l}\text { Statistical } \\
\text { Tests }\end{array}$ & Index & $\begin{array}{l}\text { Predefined } \\
\text { Model }\end{array}$ & CONGDE & $\begin{array}{l}\text { Loyalty } \\
\text { Foundation }\end{array}$ & \\
\hline Burger, R., \& Owens, T. (2010) & & $\mathrm{x}$ & & & & & $\mathrm{x}$ \\
\hline $\begin{array}{c}\text { Cabedo, J. D.Fuertes-Fuertes, } \\
\text { I.Maset-LLaudes, A. \& } \\
\text { Tirado-Beltrán, J. M. (2018) }\end{array}$ & & & $\mathrm{x}$ & & $\mathrm{x}$ & & \\
\hline Gandía, J. L. (2011) & & & & $\mathrm{x}$ & $\mathrm{x}$ & & \\
\hline $\begin{array}{l}\text { Gálvez Rodríguez, M. M. Caba } \\
\text { Pérez, M. C. Godoy, M. L. (2012) }\end{array}$ & $\mathrm{x}$ & & $x$ & & & $\mathrm{x}$ & \\
\hline $\begin{array}{l}\text { Valencia, L. A. R., Queiruga, D., } \\
\text { \& González-Benito, J. (2015) }\end{array}$ & $\mathrm{x}$ & & & & $\mathrm{x}$ & $\mathrm{x}$ & \\
\hline $\begin{array}{l}\text { Yasmin, S., Haniffa, R., \& } \\
\text { Hudaib, M. (2014) }\end{array}$ & & $\mathrm{x}$ & & & & & $\mathrm{x}$ \\
\hline
\end{tabular}

\section{Theoretical Foundations of the Transparency of Accountability in NPOs}

In this section, the term "accountability" includes the disclosing of information in response to stakeholder concerns and enabling their participation in the organization and the evaluation of performance [40,41]. This can be catalogued as a multidimensional concept [42]. The term "transparency" is linked to a variety of issues but mainly to information disclosure [30]. Taking these definitions into account, whenever we refer to "transparency in NPOs" in this document, we mean the moral practice of accountability by which organizations have to disclose information on the activities they carry out and the resources they use to achieve their social purpose, i.e., their mission [42,49]. Additionally, it is convenient to keep in mind that the academic interest in NPO transparency comes from the widespread development of the third sector over recent years $[1,48]$.

Accordingly, in the present section, we present and discuss in detail the three RQs regarding the theoretical foundations that encourage an NPO to disclose transparent information to their stakeholders. Considering all of these factors, this paper aims to answer the RQs which were previously described in the planning phase as the basis of the present study.

\subsection{RQ1: Why Should NPOs Disclose Transparent Information to Stakeholders?}

To respond to RQ1, three reasons can be stated (see Figure 4): firstly, the growing importance both in terms of size and social action of NPOs in favor of the community; secondly, the special relationship 
that NPOs have with the public sector to cover demands of specific social groups; and finally, the funding aspect from public and private donors from which they receive economic resources. These three reasons have a common aspect: The importance of building trust in the non-profit environment.

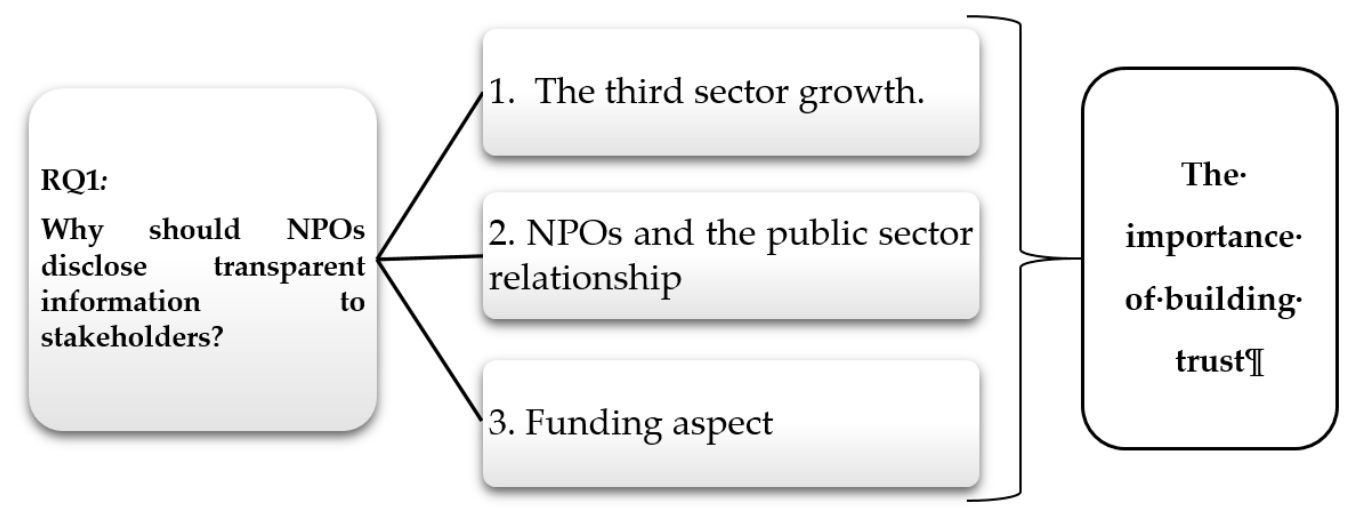

Figure 4. RQ1.

\subsubsection{Third Sector Growth and the Consequent Increase of Fraud Cases}

Third sector growth has led to an increasing interest in verifying the work carried out by these organizations in our society [73]. This evaluation demands higher levels of transparency in the information provided [76] due to a perceived lack of accountability in such information [77].

Societal pressures have become greater over the past two decades [78] due to a combination of different forces, such as social, ethical, and regulatory factors [76,79]. Thus, donors demand greater transparency of information to ensure the correct use of resources that they directly or indirectly provide to NPOs $[31,80]$.

Fraud among NPOs may be rising [7]. The literature shows that NPOs have reasons and opportunities to misreport in order to deceive interested parties [34] by adopting a position of suspicion and concealment of information [81]. In the early 2000s, several cases of financial fraud were revealed [82], as well as mismanagement in the third sector, that have challenged the notion of trust inherent in NPOs [7]. Moreover, we should also point out the fact that the moral misconduct of a single organization can damage the reputation of others that are not involved in the act [83].

Consequently, credible NPOs have an incentive to differentiate themselves from less credible ones to improve their reputation [84], because this sector cannot afford the consequences of a public scandal and a collapse of credibility, thereby affecting the capacity for donations and fundraising $[85,86]$.

\subsubsection{Cooperation with the Public Sector}

Another reason found in the literature regarding why NPOs should disclose transparent information is due to the close relationship between the public sector and the third sector, as we report below. There is a significant body of research which highlights how governments increasingly involve NPOs in the provision of social services [87] concerned with health, education, agriculture, industrial sectors, human rights, or gender issues [80]. This shows the strengths of the third sector as a provider of social goods, complementing, at the same time, the limitations of the public sector [37].

Governments consider NPOs to be a strategic partner in the provision of certain public services and in return provide financial support $[48,88]$. Therefore, NPOs constitute a fundamental part of the social economy and perform in combination with public authorities [13] despite maintaining their own autonomy [89].

Considering all of these factors, NPOs are encouraged to assume a relevant role [90] in improving the different social problems in a community. Because of such worldwide cooperation between both sectors [37], NPOs grant services in key areas as a matter of public policy [13,91]. The so-called 
"Welfare State", a system in which the public sector promises to protect its citizens, especially those in financial or social need, is suffering a deep restructuring [4]. NPOs' participation in the Welfare State is important as a consequence of their introduction into public activity.

In conclusion, this cooperation, in which public entities are one of the principal stakeholders of an NPO, also requires the disclosure of transparent information to obtain financial support from governments. This fact is even more important considering that there is a group of NPOs competing for the funds that public authorities distribute among the different organizations. This issue is discussed in the following sub-section.

\subsubsection{Public and Private Funding}

Research reveals how financial resources (private or public) in the third sector are critical to its sustainability [48] and affect its long-term success [92]. A dilemma can appear if non-profit stakeholders cannot easily observe how donations are used [93], categorizing the organization as not transparent or not trustworthy [1].

In addition, the increasing complexity and competitiveness between NPOs over the resources required [94] generates a greater responsibility in their actions and a necessary credibility that has to surround all their activities [94]. Thus, they need to have transparent systems and internal management controls that ensure that the funds they receive are maintained and managed in a prudent and responsive way $[7,30,48,50,81]$.

In summary, improving accountability and transparency is one of the most important and complex issues that the third sector is facing $[10,95]$ regarding its dependence on public trust $[77,96]$.

\subsection{RQ2: Why Do Not All NPOs Disclose Transparent Information?}

Traditionally, transparency in economic-financial information is justified by responsibility in management as well as by legal reasons related to accounting obligations, which requires compliance with minimum standards in the preparation and publication of accounts [6]. In addition, leaders of NPOs continue to give prominence to these traditional requirements [97]. Regarding this, the next question arises: is mere establishment of accounting rules sufficient to increase transparency in NPOs? In this sense, these accounting norms (e.g., financial reporting and performance management systems) are even highlighted as "imperfect accountability mechanisms" [98]. In this sense, being transparent implies more than just the presentation of the accounting information.

In contrast to this economic-financial information, however, when considering the disclosure of non-financial information, such as social information, the reality is quite different. Despite the importance of transparency, both to generate trust among stakeholders and to legitimize the NPOs themselves, there are a lack of disciplinary mechanisms [11]. There is no legal regulation that requires compliance with standards in the preparation and publication of social information in the third sector, as in other sectors [13]. This fact may discourage these entities to meet such conditions [7]. For example, NPOs have no obligation to report serious incidents-such as fraud and theft, personal behavior and financial loss- that may threaten their organization, although it is recommended that they inform others about this as a transparency mechanism [99]. In this regard, we cite external certification as an example of voluntary non-financial information. Transparency certification and the good governance of an organization can be evidenced by belonging to the CONGDE or Loyalty Foundation, as mentioned above. This assumes that non-financial information goes beyond the minimum legal regulations and is, therefore, voluntary by nature [100].

Regarding the absence of a minimum legal obligation for the NPOs to report social information, those entities who voluntarily decide to do so are faced with another problem: bureaucracy and extra costs (See Figure 5). Regarding the costs involved in generating and disclosing social information for the decision-making purposes of the stakeholders, our research highlights the potential negative consequences of a bureaucratic overload that increases the need for resources of the organizations [101]. Therefore, the entities in the third sector are concerned about the cost of preparing and disclosing 
non-financial information. NPOs are pressured by regulators, and even donors, to reveal their performance metrics and reports, incurring expensive bureaucratic tasks, which can eventually result in a misallocation of funds that are, therefore, not employed for the social mission [28].

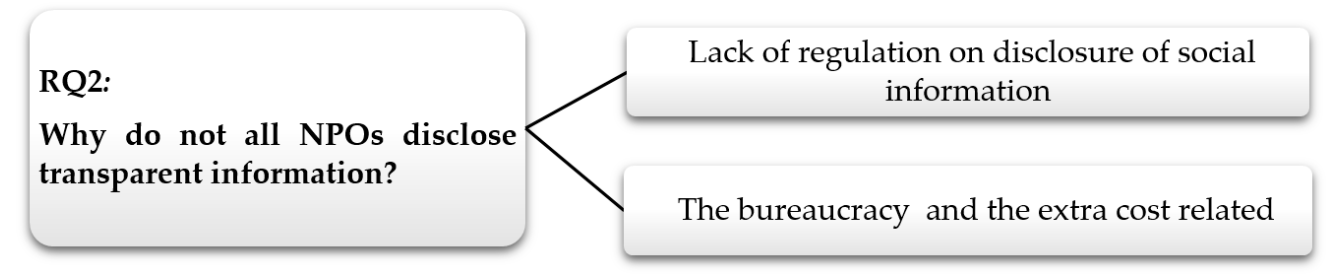

Figure 5. RQ2.

Despite the aforementioned difficulties, voluntary disclosure of information is an effective means to promote public responsibility of the NPOs [97] and improve their reputation [102]. Moreover, research shows how NPOs that are not transparent obtain lower scores in terms of public trust, reputation, perceived quality, and donation behavior [100]. In particular, there is a positive relationship between transparency, increased reputation, and the credibility of NPOs [12,103].

The conceptual rationales for not disclosing information among their stakeholders may be based on (i) a principle of rationality in cost management: NPOs, as with other organizations, seek for an appropriate balance between costs and benefits of information disclosure. Thus, the cost of obtaining (and disclosing) information (the difficulty of obtaining information or confidential information) should never exceed the benefit (increased credibility and possibilities for fundraising) that can be obtained; and (ii) a lack of guidance of how to report the information: The lack of legal, regulatory statements that specifically indicate what, when, and how information must be disclosed has led NPOs to voluntary adopt self-regulation practices. These self-regulation practices, however, imply a total margin of discretion for managers who often are in doubt regarding how to disclose information.

In conclusion, despite the lack of legal requirements for transparency, voluntary disclosure improves the perceived trustworthiness of NPOs by their stakeholders, thereby enhancing their support in favor of these entities $[45,100]$. In short, the reputation of an NPO is a crucial intangible asset that can bring noteworthy benefits to the organization [104].

\subsection{RQ3: What Means do NPOs Use to Disclose Transparent Information?}

NPOs should disclose meaningful information about their work and outcomes to their different stakeholders [26]. This is necessary because donors, funders, and the public in general have increased their demands for information [29]. Notwithstanding this higher demand, there is scant research related to this topic [69].

To begin with, let us explain how Information and Communication Technology (ICT) can help to communicate information and improve accountability $[45,105]$. The extant third sector literature highlights an important monitoring role of ICT for organizations [97], which is eventually beneficial for NPOs themselves in terms of improving public trust [105]. This advantage can be reinforced given the access in real time to updated information of the organizations by the stakeholders [36].

In general terms, the use of the Internet is changing non-profit organizational practices. Surprisingly, research in our field of study reveals the infra-use that NPOs make of the Internet as an information medium to communicate their responsibility practices in terms of transparency [42,106]. In addition, an active engagement in the age of social media is needed to reinforce organizational transparency and accountability [107].

Information disclosure through a website is the most widely used means of providing information [46]. Concerns have arisen regarding whether this kind of public information of NPOs is 
sufficient for their stakeholders in terms of the decision-making regarding the appropriate allocation of funds to that entity. The literature shows the possible limitations of website information as an accountability mechanism [79]; among other reasons, because it can be easily manipulated by the organization [46].

The advantages derived from the use of ICT in all its aspects are evident: websites, social networks, etc. Nevertheless, there is no single way to report and inform stakeholders, but each organization must establish its own mechanisms, taking into account its possibilities and experience, ensuring an effective communication with the stakeholders [6].

In summary, this review aimed to deepen our knowledge of transparency, which is as an essential issue in non-profit accountability for third-sector organizations. Based on the conceptual rationale of stakeholder theory, together with the rationality of the cost of information disclosure, we highlight how the transparency of information disclosure is essential for the fluid and efficient development of the relationships between the managers of NPOs and their stakeholders. This fact is crucial for fundraising and for the appropriate meeting of social needs by non-profit organizations. However, as evidenced in our analysis, NPOs face a great challenge in information disclosure: The lack of guidance on how to disclose information makes these entities develop particular, voluntary disclosure practices. Considering this, new insights in the literature on the third sector arise; there is a need for the creation of models that face the challenge of making the extent of transparency in NPOs quantifiable. In this sense, we can highlight from our review an important gap in prior literature: despite the importance of transparency, as previously exposed in the third sector environment, few papers in the prior literature have focused on this aspect (notwithstanding the growing tendency of work in this area of research). Moreover, among these papers, the majority have analyzed transparency from the theoretical point of view, and the rare papers that have empirically measured it have used different techniques for particular situations.

\section{Conclusions}

NPOs currently face the challenge of convincing society that they efficiently manage the funds they receive and that they are dedicated to achieving the missions for which the organizations were created. Transparency becomes a matter of vital importance that needs to be made visible. Therefore, NPOs are obliged to develop internal control mechanisms that allow their stakeholders to assess the destination of resources in accordance with their social mission. Transparency and good governance are necessary to achieve the social credibility which allows for the continuity of an organization and the achievement of its goals.

The requirement for high levels of transparency in NPOs rests on two fundamental pillars: on the one hand, public entities have become one of the main stakeholders of NPOs, requiring the disclosure of transparent information to provide financial support from public funds. This fact is even more important considering that there is a group of NPOs that compete for the funds that the public authorities distribute among the organizations. On the other hand, the inappropriate or fraudulent practices of an NPO cause severe damage, especially in the sector.

The results highlight the lack of legislation that regulates transparency procedures in the third sector. This leads NPOs to adopt voluntary policies of disclosure of information, seeking the better perception of the credibility of entities by their groups of interest. Our work shows the scarcity of published studies regarding transparency in NPOs. Once the search criteria were defined, only $12 \%$ (54 out of 449) of the articles focused on the concept of transparency in this area, and only $1.34 \%$ (6 out of 449) carried out an empirical validation of the transparency measure. Based on the total number of articles published in journals that address the NPOs $(20,037), 54$ papers dealt with transparency in the non-profit field as the main issue; this represents $0.27 \%$ of the total. Despite the increasing interest in recent years in this field, this aspect has been barely studied and efforts are required to fill this existing gap from an empirical perspective. 
From the analysis of the few empirical works published, it was deduced that there is no single way to measure transparency. Different techniques-in particular regression models, indices, and statistical tests-have been used to answer specific questions. It is necessary to study, design, and develop models that allow the quantification of the level of transparency required by each NPO and determination of the criteria used to qualify an organization as more or less transparent.

The transparency of NPOs is not an end in itself; it is a means of promoting just, peaceful, and inclusive societies, as we can see in one of the Sustainable Development Goals promulgated by the United Nations. We find, among the goals of objective 16, the creation of effective and transparent institutions at all levels that are accountable. Transparency, in short, can help to build a better world.

One possible limitation of this review is that we studied a selection of papers only from the JCR. We established the selection criterion of accepting papers only if they were published in a high-impact journal; however, we are conscious that there could be other papers that are published in journals that, despite not being indexed in JCR, could also be interesting for the understanding of transparency measurement in NPOs with important contributions. Similarly, the search keywords finally selected for such a vast field may have caused other important publications not to have been included in our sample.

Regarding the future research strategy, our SLR evidences the need for information to improve decision-making and disclosure tools in the third sector and for the improvement of measurement. The importance of appropriately quantifying the level of transparency in the organizations that constitute the third sector has also been highlighted. Future research could, therefore, look into the development of appropriate models to empirically measure the extent of an NPO in an objective, quantifiable way, to help stakeholders in decision-making. Such models can contribute to the literature from the empirical point of view, allowing NPOs to show greater levels of accountability and credibility for the stakeholders from whom they directly or indirectly receive funds or resources.

Author Contributions: Conceptualization, C.O.-R. and A.L.M.-A.; methodology, C.O.-R. and A.L.-G.; formal analysis, A.L.M.-A. and A.L.-G.; investigation, C.O.-R.; resources, A.L.-G.; writing-original draft preparation, C.O.-R.; writing-review and editing, C.O.-R., A.L.M.-A. and A.L.-G.; supervision, A.L.M.-A. and A.L.-G. All authors have read and agreed to the published version of the manuscript.

Funding: This research received no external funding.

Conflicts of Interest: The authors declare no conflict of interest.

\section{References}

1. Connolly, C.; Hyndman, N.; McConville, D. Conversion Ratios, Efficiency and Obfuscation: A Study of the Impact of Changed UK Charity Accounting Requirements on External Stakeholders. Volunt. Int. J. Volunt. Nonprofit Organ. 2013, 24, 785-804. [CrossRef]

2. Pennerstorfer, A.; Rutherford, A.C. Measuring Growth of the Nonprofit Sector: The Choice of Indicator Matters. Nonprofit Volunt. Sect. Q. 2019, 48, 440-456. [CrossRef]

3. Austin, J.E. Strategic Collaboration Between Nonprofits and Businesses. Nonprofit Volunt. Sect. Q. 2000, 29, 69-97. [CrossRef]

4. Fernández, J.M.R.; Gil, M.I.S. Una nueva frontera en organizaciones no lucrativa. CIRIEC-España Rev. Econ. Pública, Soc. y Coop. 2011, 71, 229-251.

5. Valentinov, V.; Vaceková, G. Sustainability of rural nonprofit organizations: Czech Republic and beyond. Sustainability 2015, 7, 9890-9906. [CrossRef]

6. Lozano, M.R.; Valencia, P.T.; Gutiérrez, A.C.M. Transparencia y calidad de la información económico-financiera en las entidades no lucrativas. Un estudio empírico a nivel andaluz. CIRIEC-España Rev. Econ. Pública, Soc. y Coop. 2008, 63, 253-274.

7. Greenlee, J.; Fischer, M.; Gordon, T.; Keating, E. An investigation of fraud in nonprofit organizations: Occurrences and deterrents. Nonprofit Volunt. Sect. Q. 2007, 36, 676-694. [CrossRef] 
8. Sanzo-Pérez, M.J.; Rey-Garcia, M.; Álvarez-González, L.I. The Drivers of Voluntary Transparency in Nonprofits: Professionalization and Partnerships with Firms as Determinants. Volunt. Int. J. Volunt. Nonprofit Organ. 2017, 28, 1595-1621. [CrossRef]

9. Benjamin, L.M. Account space: How accountability requirements shape nonprofit practice. Nonprofit Volunt. Sect. Q. 2008, 37, 201-223. [CrossRef]

10. Tacon, R.; Walters, G.; Cornforth, C. Accountability in Nonprofit Governance: A Process-Based Study. Nonprofit Volunt. Sect. Q. 2017, 46, 685-704. [CrossRef]

11. Burger, R.; Owens, T. Promoting transparency in the NGO sector: Examining the availability and reliability of self-reported data. World Dev. 2010, 38, 1263-1277. [CrossRef]

12. Gandía, J.L. Internet disclosure by nonprofit organizations: Empirical evidence of nongovernmental organizations for development in Spain. Nonprofit Volunt. Sect. Q. 2011, 40, 57-78. [CrossRef]

13. Hale, K. Understanding nonprofit transparency: The limit of formal regulation in the American nonprofit sector. Int. Rev. Public Adm. 2013, 18, 31-49. [CrossRef]

14. Fernández, G.C.; Vázquez, J.M.G.; Corredoira, M.D.L.Á.Q. La importancia de los Stakeholders de la organización: Un análisis empírico aplicado a la empleabilidad del alumnado de la Universidad española. Investig. Eur. Dir. y Econ. la Empres. 2007, 13, 13-32.

15. Gibson, K. The moral basis of stakeholder theory. J. Bus. Ethics 2000, 26, 245-257. [CrossRef]

16. Freeman, R.E. Strategic Management: A Stakeholder Approach; Cambridge University Press: Boston, MA, USA, 1984.

17. Volpentesta, J.R.; Chahín, T.; Alcaín, M.F.; Nievas, G.R.; Spinelli, H.E. Identificación del impacto de la gestión de los stakeholders en las estructuras de las empresas que desarrollan estrategias de responsabilidad social empresarial. Univ. Empres. 2014, 16, 65-94. [CrossRef]

18. Jeong, B.; Kearns, K. Accountability in Korean NPOs: Perceptions and Strategies of NPO Leaders. Voluntas 2015, 26, 1975-2001. [CrossRef]

19. Daub, C.H.; Scherrer, Y.M.; Verkuil, A.H. Exploring reasons for the resistance to sustainable management within non-profit organizations. Sustainability 2014, 6, 3252-3270. [CrossRef]

20. Crack, A.M. The Regulation of International NGOS: Assessing the Effectiveness of the INGO Accountability Charter. Volunt. Int. J. Volunt. Nonprofit Organ. 2018, 29, 419-429. [CrossRef]

21. INGO Accountability Charter. Our Accountability Commitments; Amnesty International: London, UK, 2015.

22. Verbruggen, S.; Christiaens, J.; Milis, K. Can resource dependence and coercive isomorphism explain nonprofit organizations' compliance with reporting standards? Nonprofit Volunt. Sect. Q. 2011, 40, 5-32. [CrossRef]

23. Costa, E.; Ramus, T.; Andreaus, M. Accountability as a Managerial Tool in Non-Profit Organizations: Evidence from Italian CSVs. Volunt. Int. J. Volunt. Nonprofit Organ. 2011, 22, 470-493. [CrossRef]

24. Young, D.R.; Jung, T.; Aranson, R. Mission-market tensions and nonprofit pricing. Am. Rev. Public Adm. 2010, 40, 153-169. [CrossRef]

25. AECA. Indicadores para Entidades Sin Fines Lucrativos; Documento no 3; International Civil Society Center: Berlin, Germany, 2012; ISBN 9788415467502.

26. Schmitz, H.P.; Raggo, P.; Bruno-van Vijfeijken, T. Accountability of transnational NGOs: Aspirations vs. practice. Nonprofit Volunt. Sect. Q. 2012, 41, 1175-1194. [CrossRef]

27. González-Sánchez, M.; Rúa-Alonso, E. Análisis de la eficiencia en la gestión de las fundaciones: Una propuesta metodológica. CIRIEC-España Rev. Econ. pública Soc. y Coop. 2007, 117-149.

28. Jepson, P. Governance and accountability of environmental NGOs. Environ. Sci. Policy 2005, 8, 515-524. [CrossRef]

29. Schatteman, A. Nonprofit accountability: To whom and for what? An introduction to the special issue. Int. Rev. Public Adm. 2013, 18, 1-6. [CrossRef]

30. Cabedo, J.D.; Fuertes-Fuertes, I.; Maset-LLaudes, A.; Tirado-Beltrán, J.M. Improving and measuring transparency in NGOs: A disclosure index for activities and projects. Nonprofit Manag. Leadersh. 2018, 28, 329-348. [CrossRef]

31. Franco, C.M.M.; Raja, I.G. Medida de la eficiencia en entidades no lucrativas: Un estudio empírico para fundaciones asistenciales. Rev. Contab. Account. Rev. 2014, 17, 47-57. [CrossRef]

32. Fritz, T.M.; von Schnurbein, G. Beyond socially responsible investing: Effects of mission-driven portfolio selection. Sustainability 2019, 11, 6812. [CrossRef] 
33. Kim, M. The Relationship of Nonprofits' Financial Health to Program Outcomes: Empirical Evidence From Nonprofit Arts Organizations. Nonprofit Volunt. Sect. Q. 2017, 46, 525-548. [CrossRef]

34. Hofmann, M.A.; McSwain, D. Financial disclosure management in the nonprofit sector: A framework for past and future research. J. Account. Lit. 2013, 32, 61-87. [CrossRef]

35. Salamon, L.M.; Sokolowski, S.W. Beyond Nonprofits: Re-conceptualizing the Third Sector. Volunt. Int. J. Volunt. Nonprofit Organ. 2016, 27, 1515-1545. [CrossRef]

36. Moreno, P.D.C.; Alcaide, T.C.H.; San Juan, A.I.S. La transparencia organizativa y económica en la Web de las fundaciones: Un estudio empírico para España. REVESCO Rev. Estud. Coop. 2016, 121, 62-88.

37. Salamon, L.M.; Toepler, S. Government-Nonprofit Cooperation: Anomaly or Necessity? Volunt. Int. J. Volunt. Nonprofit Organ. 2015, 26, 2155-2177. [CrossRef]

38. Álvarez-González, L.I.; García-Rodríguez, N.; Rey-García, M.; Sanzo-Perez, M.J. Business-nonprofit partnerships as a driver of internal marketing in nonprofit organizations. Consequences for nonprofit performance and moderators. BRQ Bus. Res. Q. 2017, 20, 112-123. [CrossRef]

39. Kuenzi, K.; Stewart, A.J. An Exploratory Study of the Nonprofit Executive Factor. J. Nonprofit Educ. Leadersh. 2017, 7, 306-324. [CrossRef]

40. Ebrahim, A. Accountability in practice: Mechanisms for NGOs. World Dev. 2003, 31, 813-829. [CrossRef]

41. O'Dwyer, B.; Unerman, J. From functional to social accountability: Transforming the accountability relationship between funders and non-governmental development organisations. Account. Audit. Account. J. 2007, 20, 446-471. [CrossRef]

42. Saxton, G.D.; Guo, C. Accountability online: Understanding the web-based accountability practices of nonprofit organizations. Nonprofit Volunt. Sect. Q. 2011, 40, 270-295. [CrossRef]

43. Arena, M.; Azzone, G.; Bengo, I. Performance Measurement for Social Enterprises. Volunt. Int. J. Volunt. Nonprofit Organ. 2015, 26, 649-672. [CrossRef]

44. Striebing, C. Professionalization and voluntary transparency practices in nonprofit organizations. Nonprofit Manag. Leadersh. 2017, 28, 65-83. [CrossRef]

45. Dumont, G.E. Transparency or Accountability? The Purpose of Online Technologies for Nonprofits. Int. Rev. Public Adm. 2013, 18, 7-29. [CrossRef]

46. Pérez, V.M.; Cruz, N.M. La web como mecanismo de transparencia de las ONG. Más allá de la certificación. Rev. Española del Terc. Sect. Sect. 2017, 137, 159-170. [CrossRef]

47. Kim, Y.H.; Kim, S.E. What Accounts for the Variations in Nonprofit Growth? A Cross-National Panel Study. Volunt. Int. J. Volunt. Nonprofit Organ. 2018, 29, 481-495. [CrossRef]

48. Gilchrist, D.J.; Simnett, R. Research horizons for public and private not-for-profit sector reporting: Moving the bar in the right direction. Account. Financ. 2019, 59, 59-85. [CrossRef]

49. Wellens, L.; Jegers, M. Effective governance in nonprofit organizations: A literature based multiple stakeholder approach. Eur. Manag. J. 2014, 32, 223-243. [CrossRef]

50. Behn, B.K.; DeVries, D.D.; Lin, J. The determinants of transparency in nonprofit organizations: An exploratory study. Adv. Account. 2010, 26, 6-12. [CrossRef]

51. Aureli, S. A comparison of content analysis usage and text mining in CSR corporate disclosure. Int. J. Digit. Account. Res. 2017, 17. [CrossRef]

52. Boell, S.K.; Cecez-Kecmanovic, D. On being 'systematic'in literature reviews. In Formulating Research Methods for Information Systems; Palgrave Macmillan: London, UK, 2015.

53. Pejić Bach, M.; Krstić, Ž.; Seljan, S.; Turulja, L. Text mining for big data analysis in financial sector: A literature review. Sustainability 2019, 11, 1277. [CrossRef]

54. Basuony, M.A.; Mohamed, E.K.; Elragal, A.; Hussainey, K. Big data analytics of corporate internet disclosures. Account. Res. J. 2020. [CrossRef]

55. Yang, R.; Yu, Y.; Liu, M.; Wu, K. Corporate risk disclosure and audit fee: A text mining approach. Eur. Account. Rev. 2018, 27, 583-594. [CrossRef]

56. Lorenzo, F.C.; Ribal, C.B.; Yánez, J.S.N. Las dimensiones socioeconómicas del Tercer Sector en Canarias. CIRIEC-España, Rev. Econ. Pública, Soc. y Coop. 2017, 89, 198-226.

57. Barea, J.; Pulido, A. El sector de instituciones sin fines de lucro en España. CIRIEC-España, Rev. Econ. Pública, Soc. y Coop. 2001, 35-49.

58. Coraggio, J.L. Las tres corrientes vigentes de pensamiento y acción dentro del campo de la Economía Social y solidaria (ESS): Sus diferentes alcances. Univ. Nac. Gen. Sarmiento Inst. del Conurbano Argentina. 2017, 15. 
59. Monzón, J.; Chaves, R. The European social economy: Concept and dimensions of the third sector. Ann. Public Coop. Econ. 2008, 79, 549-577. [CrossRef]

60. Teasdale, S. What's in a Name? Making Sense of Social Enterprise Discourses. Public Policy Adm. 2012, 27, 99-119. [CrossRef]

61. Moher, D.; Liberati, A.; Tetzlaff, J.; Altman, D.G.; PRISMA Group. Preferred Reporting Items for Systematic Reviews and Meta-Analyses: The PRISMA Statement. PLoS Med. 2009, 6, e1000097. [CrossRef]

62. Nova-Reyes, A.; Muñoz-Leiva, F.; Luque-Martínez, T. The tipping point in the status of socially responsible consumer behavior research? A bibliometric analysis. Sustainability 2020, 12, 3141. [CrossRef]

63. Dzhengiz, T. A Literature Review of Inter-Organizational Sustainability Learning. Sustainability 2020, 12, 4876. [CrossRef]

64. Ramos Montesdeoca, M.; Sánchez Medina, A.J.; Blázquez Santana, F. Research Topics in Accounting Fraud in the 21st Century: A State of the Art. Sustainability 2019, 11, 1570. [CrossRef]

65. Cordery, C.J.; Sim, D.; van Zijl, T. Differentiated regulation: The case of charities. Account. Financ. 2017, 57, 131-164. [CrossRef]

66. Bachmann, P. Some problems of Czech nonprofit sector transparency/Vybrane problemy transparentnosti ceskeho neziskoveho sektoru. E+ M Ekon. A Manag. 2012, 15, 104-115.

67. Zhuang, J.; Saxton, G.D.; Wu, H. Publicity vs. impact in nonprofit disclosures and donor preferences: A sequential game with one nonprofit organization and $\mathrm{N}$ donors. Ann. Oper. Res. 2014, 221, 469-491. [CrossRef]

68. Lu, S.; Deng, G.; Huang, C.C.; Chen, M. External environmental change and transparency in grassroots organizations in China. Nonprofit Manag. Leadersh. 2018, 28, 539-552. [CrossRef]

69. Kang, S.; Norton, H.E. Nonprofit organizations' use the World Wide Web: Are they sufficiently fulfilling organizational goals? Public Relat. Rev. 2004, 30, 279-284. [CrossRef]

70. Goatman, A.K.; Lewis, B.R. Charity e-volution? An evaluation of the attitudes of UK charities towards website adoption and use. Int. J. Nonprofit Volunt. Sect. Mark. 2007, 12, 33-46. [CrossRef]

71. Waters, R.D. Nonprofit organizations' use of the Internet. A content analysis of com- munication trends on the Internet sites of the philanthropy 400. Nonprofit Manag. Leadersh. 2007, 18, 59-76. [CrossRef]

72. CONGDE. La Transparencia y Rendición de Cuentas en las ONGD: Situación Actual y Retos; CONGDE: Madrid, Spain, 2007.

73. Gálvez Rodríguez, M.M.; Caba Pérez, M.C.; Godoy, M.L. Determining Factors in Online Transparency of NGOs: A Spanish Case Study. Volunt. Int. J. Volunt. Nonprofit Organ. 2012, 23, 661-683. [CrossRef]

74. Valencia, L.A.R.; Queiruga, D.; González-Benito, J. Relationship Between Transparency and Efficiency in the Allocation of Funds in Nongovernmental Development Organizations. Volunt. Int. J. Volunt. Nonprofit Organ. 2015, 26, 2517-2535. [CrossRef]

75. Yasmin, S.; Haniffa, R.; Hudaib, M. Communicated Accountability by Faith-Based Charity Organisations. J. Bus. Ethics 2014, 122, 103-123. [CrossRef]

76. Rey-Garcia, M.; Liket, K.; Alvarez-Gonzalez, L.I.; Maas, K. Back to Basics: Revisiting the relevance of beneficiaries and for evaluation and accountability in nonprofits. Nonprofit Manag. Leadersh. 2017, 27, 493-511. [CrossRef]

77. Yang, C.; Northcott, D. How can the public trust charities? The role of performance accountability reporting. Account. Financ. 2019, 59, 1687-1713. [CrossRef]

78. McDonnell, D.; Rutherford, A.C. Promoting charity accountability: Understanding disclosure of serious incidents. Account. Forum 2019, 43, 42-61. [CrossRef]

79. Carnochan, S.; Samples, M.; Myers, M.; Austin, M.J. Performance Measurement Challenges in Nonprofit Human Service Organizations. Nonprofit Volunt. Sect. Q. 2014, 43, 1014-1032. [CrossRef]

80. Amagoh, F. Improving the credibility and effectiveness of non-governmental organizations. Prog. Dev. Stud. 2015, 15, 221-239. [CrossRef]

81. de Andrés-Alonso, P.; Azofra-Palenzuela, V.; Romero-Merino, M.E. Determinants of Nonprofit Board Size and Composition. Nonprofit Volunt. Sect. Q. 2009, 38, 784-809. [CrossRef]

82. Neely, D.G. The impact of regulation on the US nonprofit sector: Initial evidence from the Nonprofit Integrity Act of 2004. Account. Horiz. 2011, 25, 107-125. [CrossRef]

83. Hielscher, S.; Winkin, J.; Crack, A.; Pies, I. Saving the Moral Capital of NGOs: Identifying One-Sided and Many-Sided Social Dilemmas in NGO Accountability. Volunt. Int. J. Volunt. Nonprofit Organ. 2017, 28, 1562-1594. [CrossRef] 
84. Tremblay-Boire, J.; Prakash, A. Accountability. org: Online disclosures by US nonprofits. Volunt. Int. J. Volunt. Nonprofit Organ. 2015, 26, 693-719. [CrossRef]

85. Gibelman, M.; Gelman, S.R. A loss of credibility: Patterns of wrongdoing among nongovernmental organizations. Volunt. Int. J. Volunt. Nonprofit Organ. 2004, 15, 355-381. [CrossRef]

86. Liu, Y.; Zhang, M.; Ye, T.; Zhang, Y. Does giving always lead to getting? Evidence from the collapse of charity credibility in China. Pac.-Basin Financ. J. 2019, 58, 101207. [CrossRef]

87. Feiock, R.C.; Andrew, S.A. Introduction: Understanding the Relationships Between Nonprofit Organizations and Local Governments. Int. J. Public Adm. 2006, 29, 759-767. [CrossRef]

88. Boateng, A.; Akamavi, R.K.; Ndoro, G. Measuring performance of non-profit organisations: Evidence from large charities. Bus. Ethics 2016, 25, 59-74. [CrossRef]

89. Neumayr, M.; Schneider, U.; Meyer, M. Public Funding and Its Impact on Nonprofit Advocacy. Nonprofit Volunt. Sect. Q. 2015, 44, 297-318. [CrossRef]

90. Manville, G.; Greatbanks, R. Third Sector Performance: Management and Finance in Not-for-Profit and Social Enterprises; Routledge: Abington, UK, 2016; ISBN 9781409429616.

91. Weidenbaum, M. Who will guard the guardians? The social responsibility of NGOs. J. Bus. Ethics 2009, 87, 147-155. [CrossRef]

92. Keating, E.K.; Frumkin, P. Reengineering nonprofit financial accountability: Toward a more reliable foundation for regulation. Public Adm. Rev. 2003, 63, 3-15. [CrossRef]

93. Haski-Leventhal, D.; Foot, C. The Relationship Between Disclosure and Household Donations to Nonprofit Organizations in Australia. Nonprofit Volunt. Sect. Q. 2016, 45, 992-1012. [CrossRef]

94. Lequericaonandia, M.B.V.; Galiana, M.E.I. Siguen las ONG Españolas los mecanismos voluntarios de accountability? Análisis del seguimiento de un grupo de ONG Españolas de los principios propuestos por la fundación lealtad. REVESCO Rev. Estud. Coop. 2014, 115, 186-214. [CrossRef]

95. Benjamin, L.M. The Potential of Outcome Measurement for Strengthening Nonprofits' Accountability to Beneficiaries. Nonprofit Volunt. Sect. Q. 2013, 42, 1224-1244. [CrossRef]

96. Saxton, G.D.; Kuo, J.S.; Ho, Y.C. The Determinants of Voluntary Financial Disclosure by Nonprofit Organizations. Nonprofit Volunt. Sect. Q. 2012, 41, 1051-1071. [CrossRef]

97. Lecy, J.D.; Schmitz, H.P.; Swedlund, H. Non-Governmental and Not-for-Profit Organizational Effectiveness: A modern synthesis. Volunt. Int. J. Volunt. Nonprofit Organ. 2012, 23, 434-457. [CrossRef]

98. Goncharenko, G. The accountability of advocacy NGOs: Insights from the online community of practice. Account. Forum 2019, 43, 135-160. [CrossRef]

99. Becker, A. An Experimental Study of Voluntary Nonprofit Accountability and Effects on Public Trust, Reputation, Perceived Quality, and Donation Behavior. Nonprofit Volunt. Sect. Q. 2018, 47, 562-582. [CrossRef]

100. Moxham, C.; Boaden, R. The impact of performance measurement in the voluntary sector. Int. J. Oper. Prod. Manag. 2007, 27, 826-845. [CrossRef]

101. Cordery, C.J.; Morgan, G.G. Special Issue on Charity Accounting, Reporting and Regulation. Volunt. Int. J. Volunt. Nonprofit Organ. 2013, 24, 757-759. [CrossRef]

102. AbouAssi, K. Testing Resource Dependency as a Motivator for NGO Self-Regulation: Suggestive Evidence From the Global South. Nonprofit Volunt. Sect. Q. 2015, 44, 1255-1273. [CrossRef]

103. Peng, S.; Kim, M.; Deat, F. The Effects of Nonprofit Reputation on Charitable Giving: A Survey Experiment. Volunt. Int. J. Volunt. Nonprofit Organ. 2019, 30, 811-827. [CrossRef]

104. Lee, R.L.; Joseph, R.C. An examination of web disclosure and organizational transparency. Comput. Hum. Behav. 2013, 29, 2218-2224. [CrossRef]

105. Puentes, R.; Mozas, A.; Bernal, E.; Chaves, R. E-corporate social responsibility in small non-profit organisations: The case of Spanish 'Non Government Organisations'. Serv. Ind. J. 2012, 32, 2379-2398. [CrossRef]

106. Long, Z. Managing legitimacy crisis for state-owned non-profit organization: A case study of the Red Cross Society of China. Public Relat. Rev. 2016, 42, 372-374. [CrossRef]

107. Pavlovic, J.; Lalic, D.; Djuraskovic, D. Communication of Non-Governmental Organizations via Facebook Social Network. Eng. Econ. 2014, 25, 186-193. [CrossRef]

(C) 2020 by the authors. Licensee MDPI, Basel, Switzerland. This article is an open access article distributed under the terms and conditions of the Creative Commons Attribution (CC BY) license (http://creativecommons.org/licenses/by/4.0/). 